\title{
A New Method for the Intensive Isolation of Actinomycetes from Soil
}

\author{
Masayuki Hayakawa and Hideo Nonomura
}

Department of Fermentation Technology, Faculty of Engineering, Yamanashi University, Takeda-4, Kofu 400, Japan

(Received Mar. 29, 1989 / Accepted Sep. 30, 1989)

\begin{abstract}
A new method was developed to isolate actinomycetes from soil more selectively and more thoroughly.

Elements of the procedure are (1) treatment of soil suspension with a solution containing yeast extract (YE) $6 \%$ and sodium dodecyl sulfate (SDS) $0.05 \%$, at $40^{\circ} \mathrm{C}$ for $20 \mathrm{~min}$, (2) subsequent dilution with water and (3) a few week's incubation on HV agar plates containing nalidixic acid (n.a.) $20 \mathrm{mg} / \mathrm{L}$.

The YB and the heat shock at $40^{\circ} \mathrm{C}$ activated spore germination of a variety of actinomycete strains, the SDS acted as a germicide only on bacterial cells with rare exception, and the n.a. suppressed growth of bacterial spore formers without any effect on the actinomycetes, under the conditions used.

By the treatment of soil suspension with YB and SDS, the count of actinomycete cfu per $\mathrm{g}$. of various soils ( $10 \mathrm{samples)}$ ) was increased by $40 \%$ and the count of bacteria was decreased to $20 \%$, on the averages. The bacterial count was further decreased to less than $10 \%$ by addition of n.a. into the isolation medium.
\end{abstract}

Actinomycetes are widely distributed in soil and constitute a significant part of soil microflora1). Selective isolation methods for these organisms are important for studying their ecology as well as for screening of industrially useful strains.

Various methods have been developed for the preferential isolation of general actinomycetes from soil. These methods include a variety of selective isolation media supplemented with certain antibiotics ${ }^{2-6)}$, and the pretreatments of soil sample or soil suspension by enrichment ${ }^{7}$, heating ${ }^{8,9}$ ), membrane filtration ${ }^{10)}$, or use of chemicals such as phenol11), benzalkonium chloride ${ }^{12}$, etc. Recently, the specific procedures for isolating particular genera or groups of actinomycetes have also been developed ${ }^{13-24)}$.

As the actinomycetes are generally outnumbered by other bacteria in their habitat such as soil, many of the isolation methods have been designed to eliminate undesirable bacteria from inocula or to suppress the bacterial growth on isolation media, while preserving the viability of actinomycetes. However, following problems of the isolation procedures still remain: (i) any of the isolation media are not absolutely selective for actinomy- cetes 12,25 ), and (ii) some of the pretreatments and incorporation of antibacterial antibiotics into isolation media cause the reduction in the number of actinomycetes $2,4,25,28$ ).

In this paper, we describe a new method for isolating general actinomycetes from soil, whereby the number of actinomycete colonies can be increased whereas bacterial colonies effectively decreased on the isolation plates. It includes the pretreatment of soil suspension with a spore activating agent (yeast extract) and a germicide (sodium dodecyl sulfate: detergent), and use of a selective isolation medium, HV agar ${ }^{27}$ ) containing nalidixic acid.

\section{MATERIALS AND METHODS}

Strains. Thirty-five strains of bacteria including 27 strains of actinomycetes (Table 2) were used. Sources of these strains are as follows: International Streptomyces Project (ISP); Institute for Fermentation, Osaka, Japan (IFO); Northern Utilization Research and Development Division, US Department of Agriculture, Peoria, Illinois (NRRL); Japan Collection of Microorganisms, RIKEN, Saitama, Japan (JCM); American Type Culture Collection, Rockville, Maryland (ATCC); Centraalbureau voor 
Schimmelkultures, Baarn, Netherlands (CBS); Central Research Laboratories, Kaken Chemical Co., Ltd., Tokyo, Japan (KCC); Institute of Applied Microbiology, University of Tokyo, Japan (IAM); Laboratory strains (M6, Nonomura and Ohara, 196028); S9, Nonomura and Ohara, $\left.1960^{29}\right)$; T80, Nonomura and Ohara, $\left.1971^{16)}\right)$.

Actinomycete strains were stored on oatmeal agar $\mathrm{YGG}^{4}$ ) or yeast starch agar ${ }^{31}$ ) slants.

Soil samples. As shown in Table 1, fourteen samples were used. The samples were collected and preserved by the methods previously described ${ }^{30}$ ). A portion of the preserved soil was passed through a $2 \mathrm{~mm}$-mesh sieve, air-dried at room temperature for one week and used for the isolation of actinomycetes as well as for chemical analysis ${ }^{27}$.

Spore activating agents and germicide. The chemicals used are as follows: yeast extract (YE; Difco, U.S.A.), sodium dodecyl sulfate (SDS; Tokyo Kasei Co.), L-valine (Va; Wako Pure Chemical Ind. Ltd., Osaka), mercaptoethanol (ME; Wako), vitamin assay casamino acids (CA; Difco), and humic acid (HA; $\underline{R F} 21.3$, $\Delta \log \underline{\mathrm{K}}$ 0.84) which was prepared from soil of mountain forest by the method previously described 27 ). The humic acid was used also as a nutrient of $\mathrm{HV}$

Table 1. Soil samples used for isolation of actinomycetes.

\begin{tabular}{clrrr}
\hline $\begin{array}{c}\text { Sample } \\
\text { No. }\end{array}$ & $\begin{array}{c}\text { Prefec- } \\
\text { ture }\end{array}$ & $\begin{array}{c}\text { Type* on } \\
\text { ignition } \\
(\%)\end{array}$ & pH \\
\hline 323 & Yamanashi & Fi & 15.7 & 5.3 \\
346 & Nagano & mF & 23.2 & 5.3 \\
375 & Yamanashi & Fi & 7.2 & 6.1 \\
377 & Yamanashi & Fi & 6.9 & 6.5 \\
378 & Yamanashi & IF & 16.7 & 5.8 \\
381 & Yamanashi & P & 12.7 & 5.8 \\
384 & Yamanashi & Fi & 17.4 & 5.8 \\
388 & Yamanashi & Pa & 22.3 & 6.3 \\
389 & Nagano & Fi & 22.9 & 7.2 \\
401 & Yamanashi & P & 6.0 & 5.1 \\
403 & Nagano & Fi & 22.8 & 6.2 \\
405 & Yamanashi & Fi & 16.1 & 5.8 \\
406 & Nagano & Fi & 15.7 & 6.2 \\
407 & Nagano & Fi & 21.1 & 6.0 \\
\hline
\end{tabular}

* Fi: field (non paddy, cultivated), $\mathrm{mF}$ : mountain forest,

IF: level-land forest,

$\mathrm{P}$ : paddy field, $\mathrm{Pa}$ : pasture. $\operatorname{agar} 27$ ).

These agents were dissolved in $5 \mathrm{mM}$-phosphate buffer $(\mathrm{pH} 7.0)$ and sterilized separately by autoclaving, except for ME which was added to a sterile phosphate buffer solution. The $\mathrm{pH}$ value of each solution was adjusted to 7.0 with $2 \mathrm{~N} \mathrm{NaOH}$ or $1 \mathrm{~N} \mathrm{HCl}$ before autoclaving.

Preparation of spore- or bacterial cell-suspensions. Actinomycete strains were inoculated on the plates of oatmeal agar $\left.\mathrm{Y}^{28}\right)(\mathrm{pH} 7.2$, for the strains of Streptomyces, Actinomadura, Microtetraspora niveoalba, Mit. glauca, Streptosporangium, Nocardia, Dactylosporangium and Actinoplanes; $\mathrm{pH}$ 6.5, for the strains of Microbispora) or yeast starch agar31) $(\mathrm{pH} 7.2$, for the strains of Micromonospora; $\mathrm{pH} 8.0$, for the strains of Mit. viridis, Thermomonospora and Saccharomonospora). The cultures were incubated at $30^{\circ} \mathrm{C}$ for 4 weeks, except for the strains of Thermomonospora, Mit. viridis, Mit. niveoalba and Saccharomonospora which were incubated at $35^{\circ} \mathrm{C}$, subsequently stored at $5^{\circ} \mathrm{C}$ for about one month. Spores were scraped off the agar surface with an inoculating needle and collected in $5 \mathrm{ml}$ of sterile tap water $\left(15^{\circ} \mathrm{C}\right)$. The tube was vigorously stirred on a Thermo-mixer (Thermonics Co., Tokyo) and sonicated for $15 \mathrm{sec}$. in an ultrasonic bath $(45 \mathrm{Kz}, 15 \mathrm{~W}$ : Branson Ultrasonic Corp., U.S.A.). The spore suspension was then passed twice through a $5.0 \mu \mathrm{m}$ pore size membrane (Gelman Science Inc., U.S.A.) to remove mycelial fragments and diluted with sterile tap water at a density of $1 \times 10^{7}$ spores $/ \mathrm{ml}$.

The strains of other bacteria were inoculated on nutrient agar ${ }^{32)}$ slants and incubated at $30^{\circ} \mathrm{C}$ for a day. Cell suspension was prepared by transferring the culture to sterile tap water at a density of $1 \times 10^{7} / \mathrm{ml}$. Spores of the Bacillus strain were scraped off the nutrient agar slant culture incubated at $25^{\circ} \mathrm{C}$ for 10 days and collected in sterile tap water. The suspension was used after heating at $80^{\circ} \mathrm{C}$ for $15 \mathrm{~min}$. to kill vegetative cells ${ }^{33}$ ).

Recovery from spore- or bacterial cell-suspension after pretreatment with YE or SDS. To prepare an inoculum, $0.5 \mathrm{ml}$ of spore- or bacterial cellsuspension was transferred to $4.5 \mathrm{ml}$ of 5 mM-phosphate buffer ( $\mathrm{pH} 7.0$ ) containing either YE (at the final concentration of $6 \%, \mathrm{w} / \mathrm{v}$ ) or SDS (at the final 
Table 2. Recovery from actinomycete spore- and bacterial cell-suspensions after the pretreatment and dilution, and sensitivity to nalidixic acid (NA), on agar plates.

\begin{tabular}{|c|c|c|c|c|}
\hline \multirow[t]{2}{*}{ Species } & \multicolumn{3}{|c|}{$\begin{array}{l}\text { Colony formation on HV } \\
\text { agar, \% to the control }\end{array}$} & \multirow{2}{*}{$\begin{array}{l}\text { Growth on } \\
\text { HV-N agare) } \\
\text { plus } \\
\text { NA }\end{array}$} \\
\hline & $\underset{(\text { Ben)a }}{\text { control }} \mathrm{P}$ & Pretreat & ment $b$ ) & \\
\hline \multirow{2}{*}{\multicolumn{5}{|c|}{ (Actinomycetes)* }} \\
\hline & & & & \\
\hline Streptomyces viridochromogenes ISP 5110 & $100(86)$ & 138 & 113 & + \\
\hline Streptomyces gougeroti IFO 3198 & $100(88)$ & 118 & 89 & + \\
\hline Streptomyces coelicolor IFO 3504 & $100(110)$ & 121 & 126 & + \\
\hline Streptomyces antibioticus IFO 3126 & $100(79)$ & 111 & 35 & + \\
\hline Streptomyces flaveolus IFO 3408 & $100(106)$ & 105 & 61 & + \\
\hline Streptomyces flavus IFO 3359 & $100(63)$ & 124 & 61 & + \\
\hline Streptomyces albus IFO 3418 & $100(230)$ & 134 & 126 & + \\
\hline Streptomyces lavendulae IFO 3177 & $100(98)$ & 128 & $0 * *$ & + \\
\hline Micromonospora carbonaceae NRRL 2972 & $100(96)$ & 118 & 121 & + \\
\hline Micromonospora chalcea JCM 3031 & $100(50)$ & 130 & 96 & + \\
\hline Micromonospora megalomicea IFO 14114 & $100(73)$ & 108 & 113 & + \\
\hline Microbispora amethystogenes M10 & $100(83)$ & 112 & 104 & + \\
\hline Microbispora diastatica M6 & $100(56)$ & 130 & 101 & + \\
\hline Microbispora rosea ATCC 12950 & $100(51)$ & 103 & 39 & + \\
\hline Microbispora chromogenes CBS 304.61 & $100(60)$ & 106 & 78 & + \\
\hline Actinomadura verrucosospora ATCC 27299 & $100(105)$ & 140 & 106 & + \\
\hline Actinomadura roseoviolaceae ATCC 27297 & $100(70)$ & 121 & 61 & + \\
\hline Actinomadura pussilla ATCC 27296 & $100(64)$ & 104 & 95 & + \\
\hline Microtetraspora viridis ATCC 27103 & $100(59)$ & & 126 & + \\
\hline Microtetraspora niveoalba ATCC 27301 & $100(84)$ & 127 & 120 & + \\
\hline Microtetraspora glauca ATCC 27645 & $100(89)$ & 116 & 104 & + \\
\hline Streptosporangium roseum $\mathrm{s} 9$ & $100(101)$ & 120 & 74 & + \\
\hline Nocardia asteroides JCM 3384 & $100(111)$ & 132 & 74 & + \\
\hline Saccharomonospora viridis $\mathrm{T} 80$ & $100(33)$ & 115 & 80 & + \\
\hline Thermomonospora mesophila ATCC 27303 & $100(87)$ & 114 & 57 & + \\
\hline Dactylosporangium thailandense $\mathrm{KCC}$ A0084 & $100(174)$ & 111 & 113 & + \\
\hline Actinoplanes brasiliensis KCC A0196 & $100(110)$ & 90 & 0 & + \\
\hline \multicolumn{5}{|l|}{ (Bacteria) } \\
\hline Bacillus subtilis IAM 1069 & 100 & & 0 & - \\
\hline Bacillus cereus IAM 1072 & 100 & & 0 & $\perp$ \\
\hline Micrococcus lysoideikticus IAM 1056 & 100 & & 0 & + \\
\hline Brevibacterium ammoniagenes IAM 1641 & 100 & & 0 & $\perp$ \\
\hline Pseudomonas putida IAM 1506 & 100 & & 0 & $\perp$ \\
\hline Pseudomonas saccharophila IAM 1504 & 100 & & 0 & $\perp$ \\
\hline Flavobacterium sewanense IAM 1014 & 100 & & 0 & + \\
\hline Escherichia coli IFO 3044 & 100 & & 84 & - \\
\hline Spores (B. subtilis IAM 1069) & 100 & & 136 & \\
\hline
\end{tabular}

a) Bennett's agar as a control to HV agar.

b) YE (yeast extract) 6\%, SDS (sodium dodecyl sulfate) $0.05 \%$, in $5 \mathrm{mM}$ phosphate buffer $(\mathrm{pH} 7.0)$ at $40^{\circ} \mathrm{C}$ for $20 \mathrm{~min}$.

c) cf. text.

*Spores from stocked $\left(5^{\circ} \mathrm{C}\right.$, one month) cultures, filtered to remove mycelial fragments.

**In combined use with YE, up to $30 \%$ survived. 
concentration of $0.05 \%, w / v)$, and maintained at $40^{\circ} \mathrm{C}$ for $20 \mathrm{~min}$ with occasional stirring. A portion was then further diluted with sterile tap water $(1: 1,000)$. Inocula of $0.1 \mathrm{ml}$ were spread over the 5 plates of HV agar with a sterile glass rod. The plates were incubated at $30^{\circ} \mathrm{C}$ (except for the strains of Thermomonospora, Microtetraspora viridis, Mit. niveoalva and Saccharomonospora which were incubated at $\left.35^{\circ} \mathrm{C}\right)$ for 10-14 days, following which colonies appeared were counted. Untreated spore- or bacterial cell-suspension (control) was also diluted with sterile tap water, inoculated on the plates of HV agar and of Bennett's agar ${ }^{45}$ ), and incubated, under the same conditions.

Sensitivity test to nalidixic acid. HV agar supplemented with $0.1 \%$ (w/v) beef extract, $0.1 \%(\mathrm{w} / \mathrm{v})$ peptone and $0.05 \%(\mathrm{w} / \mathrm{v}) \mathrm{NaCl}$ was used as basal medium (HV-N agar). Nalidixic acid (Sigma Chemical Co., U.S.A.) was dissolved in $0.1 \mathrm{~N} \mathrm{NaOH}(20 \mathrm{mg} / 2 \mathrm{ml}$, sterile) and added to the autoclaved $\mathrm{HV}-\mathrm{N}$ agar.

Inocula of actinomycetes were prepared by suspending one loopful of spores from slant culture into $1 \mathrm{ml}$ of sterile tap water. For other bacteria, the nutrient broth cultures incubated on a shaker at $30^{\circ} \mathrm{C}$ for overnight were used as the inocula. About $0.05 \mathrm{ml}$ of the spore suspension or one loopful bacterial culture was streaked on the surface of $\mathrm{HV}-\mathrm{N}$ agar containing $20 \mathrm{mg} / \mathrm{L}$ nalidixic acid. These plates were incubated and the growth was scored after 14 days (for actinomycetes) or 7 days (for other bacteria).

Selective isolation procedure for actinomycetes. One gram of air-dried soil sample was added to $10 \mathrm{ml}$ of sterile tap water in a tube and stirred for $1 \mathrm{~min}$. on a Thermo Mixer. After allowing the tube to stand for $1 \mathrm{~min}$. to precipitate coarse sand, $0.5 \mathrm{ml}$ of the supernatant was removed to $4.5 \mathrm{ml}$ of sterile 5 mM-phosphate buffer (pH 7.0) containing spore activating agent and germicide separately or in combination. The mixture was maintained at $40^{\circ} \mathrm{C}$ for 20 min. with occasional stirring. A portion $(1 \mathrm{ml})$ was then further diluted with sterile tap water $(1: 1,000)$ by the 10-fold dilution method ${ }^{13}$ ). Inocula of 0.1 or $0.2 \mathrm{ml}$ were spread over the surface of 7-10 plates of HV agar ${ }^{27}$ ) and incubated for 3 weeks at $30^{\circ} \mathrm{C}$. Colonies of actinomycetes and other bacteria which appeared on the plates were examined with the naked eyes and a light microscope. The numbers of colonies were determined from the mean counts of the 7-10 plates and results were statistically analysed as previously described ${ }^{30}$ ). Untreated soil suspension (control) was also diluted with sterile tap water, inoculated on HV agar plates and incubated, under the same conditions.

\section{RESULTS}

Effects of each agent of the new method on spores or cells from pure cultures. The effect of the pretreatment $\left(40^{\circ} \mathrm{C}, 20 \mathrm{~min}.\right)$ with yeast extract (YE) or sodium dodecyl sulfate (SDS) was confirmed using 35 species of actinomycetes and other bacteria. Details of the results are shown in Table 2. The pretreatment with YE increased the recovery\% (colonies from spores) of many of the actinomycete strains tested. In contrast, the recovery\% on Bennett's agar, which contains $\mathrm{YE}$ as a nutrient, were generally lower than those on HV agar. Agent SDS killed vegetative cells of the test soil bacteria including the strains of Bacillus, Pseudomonas and Brevibacterium genera, but this agent was harmless, with rare exception, to the spores of actinomycete strains and of $B$. subtilis. The recovery of several actinomycete strains tested was increased by the SDS treatment.

Results of the sensitivity test of actinomycetes and other bacteria against the antibiotic nalidixic acid are also given in Table 2. Nalidixic acid (20 $\mathrm{mg} / \mathrm{L})$ in $\mathrm{HV}-\mathrm{N}$ agar had no effect on the growth of actinomycete strains examined, but suppressed the growth of the soil bacteria. The sporogenous species of $B$. subtilis was completely inhibited.

Mild heat treatment of soil suspension. Figure 1 shows the changes of the number of actinomycetes on isolation plates brought by the heating of a soil suspension in phosphate buffer at $40^{\circ} \mathrm{C}$ or $50^{\circ} \mathrm{C}$ for various periods. The treatment for proper time increased in number of actinomycetes on the plates, especially at $40^{\circ} \mathrm{C}$ for $20 \mathrm{~min}$. resulted in the highest recovery of actinomycetes.

The effect of this treatment $\left(40^{\circ} \mathrm{C}\right.$, 
30 min.) was also examined for 6 other soil samples, and confirmed the increase in number of actinomycetes on isolation plates by $13 \%(0-28 \%)$ on an average (details not shown).

Effects of various spore activating agents on isolation of actinomycetes. considering the results mentioned above, we investigated the effects of the pretreatments of soil suspension with these spore activating agents and with their relatives, such as casamino acid (CA), valine (Va), humic acid (HA) and mercaptoethanol (ME), on the isolation of actinomycetes.

The following concentrations (\%, w/v) of the agents were used individually in soil pretreatment $\left(40^{\circ} \mathrm{C}, 20 \mathrm{~min}.\right)$ for isolation of actinomycetes from 2 soil samples: $\mathrm{YE}(1,2$ and 4$), \mathrm{HA}(0.2,1$ and 2), $\mathrm{CA}(0.5,1$ and 2$), \mathrm{Va}(0.1,0.2$ and $0.5), M E(0.1,0.2$ and 0.4$)$ and SDS $(0.05$ and 0.1$)$. Table 3 shows the efficiencies of the pretreatments with individual agents at the optimal concentrations for isolating actinomycetes from a soil sample No. 405. The pretreatments clearly increased the number of actinomycete cfu (colony forming unit); the treatment with $2 \%$ YE gave the

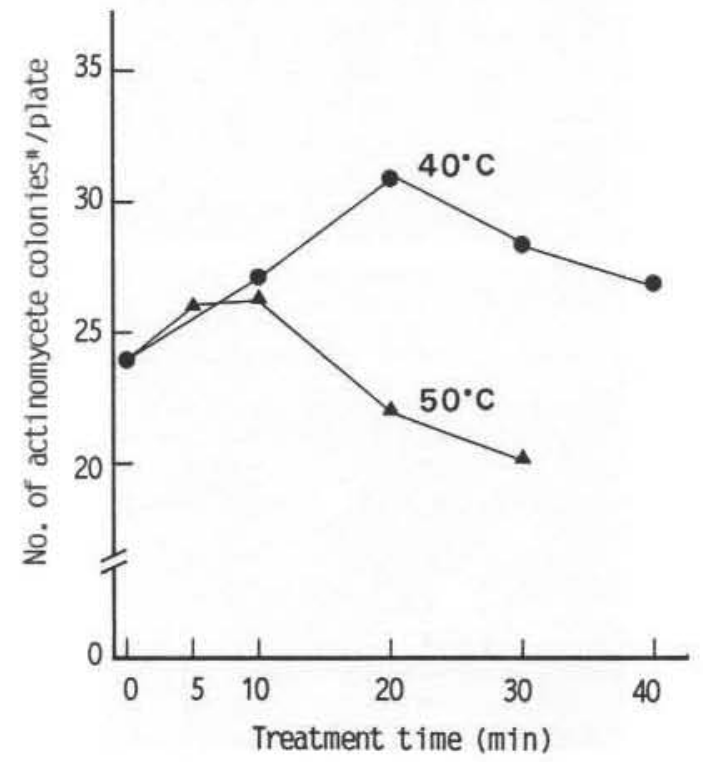

Fig. 1. Increase of actinomycete colonies by heat treatment at $40^{\circ} \mathrm{C}$ and $50^{\circ} \mathrm{C}$ in $\mathrm{P}$-buffer ( $5 \mathrm{mM}, \mathrm{pH}$ 7.0) suspension. (Soil No. 407, HV agar)

- After 3 weeks at $30^{\circ} \mathrm{C}$. largest number of actinomycete cfu, followed by the treatment with $2 \%$ HA. The number of actinomycete cfu brought by the YE- or the HA-treatment was significantly $(\mathrm{P}<0.01)$ larger than the number obtained from untreated inocula (control). On the other hand, the treatments with SDS and HA significantly $(P<0.001)$ decreased bacterial counts. For another soil sample (No. 406), the results obtained were similar to those in Table 3. Therefore it was planed to investigate the effects of the combined use of SDS (as a germicide to soil bacteria) with spore activating agents in the pretreatment of soil sample.

Effects of combined use of SDS with spore activating agents. In Figure 2, optimal concentrations of SDS and YE in combined use are shown, using a soil sample No. 405. In a combined use of $0.05 \%$ SDS and $6 \%$ YE, remarkable decrease in bacterial number and distinct increase in actinomycete number were observed.

Agents $\mathrm{HA}, \mathrm{Va}, \mathrm{CA}$ and $\mathrm{ME}$ were also combined individually with $0.05 \%$ SDS in treatment of soil suspension and investigated their optimal concentrations for isolating actinomycetes from a soil sample No. 405. The efficiencies of the combined uses of $0.05 \%$ SDS and individu-

Table 3. Effects of various spore-activating agents on isolation of actinomycetes from a soil sample (No. 405).

\begin{tabular}{|c|c|c|}
\hline \multirow{2}{*}{$\begin{array}{l}\text { Treatment* } \\
40^{\circ} \mathrm{C}, 20 \mathrm{~min} .\end{array}$} & \multicolumn{2}{|c|}{$\begin{array}{l}\text { No. of colonies } \\
(\mathrm{cfu} / \mathrm{g} \text { of soil }\end{array}$} \\
\hline & Actino- & Bacteria \\
\hline None (Control) & $117(100)$ & $152(100)$ \\
\hline Heat shock $\left(40^{\circ} \mathrm{C}\right)$ & 136 (116) & $155(102)$ \\
\hline YE $2 \%$ & $192(164)$ & 169 (111) \\
\hline HA $2 \%$ & $183(156)$ & $92(60)$ \\
\hline CA $1 \%$ & $170(145)$ & $165(109)$ \\
\hline Va $0.2 \%$ & 159 (136) & 178 (117) \\
\hline ME $0.2 \%$ & $163(139)$ & $136(89)$ \\
\hline SDS $0.1 \%$ & $152(130)$ & $10(7)$ \\
\hline
\end{tabular}

*YE: yeast extract, HA: humic acid, CA: casamino acid, Va: valine, ME: mercaptoethanol, SDS: sodium dodecyl sulfate, each in $5 \mathrm{mM}$-phosphate buffer $(\mathrm{pH} \mathrm{7.0)}$. HV agar was used for isolation.

**After 3 weeks at $30^{\circ} \mathrm{C}$. 
al agents at the optimal concentrations are compared in Table 4. Among the various combinations, a combination of $0.05 \%$ SDS and $6 \%$ YE produced the largest number of actinomycete cfu, while decreased the bacterial counts. The number of actinomycete cfu brought by the combined use of SDS and YE was significantly $(\mathrm{P}<0.001)$ larger than the number obtained from untreated inocula (control). Figure 3 shows the example of the isolation plates. On the isolation plate inoculated with the dilutant of soil suspension that had been treated with the pair of SDS and YE, the numbers of actinomycete colonies are larger than the numbers on control plate, while bacterial colonies are very few.

Figure 4 shows that the pretreatment of a soil suspension with a combination of SDS and YE gave rise to a great increase in the number of actinomycete colonies on isolation plates in a few days.

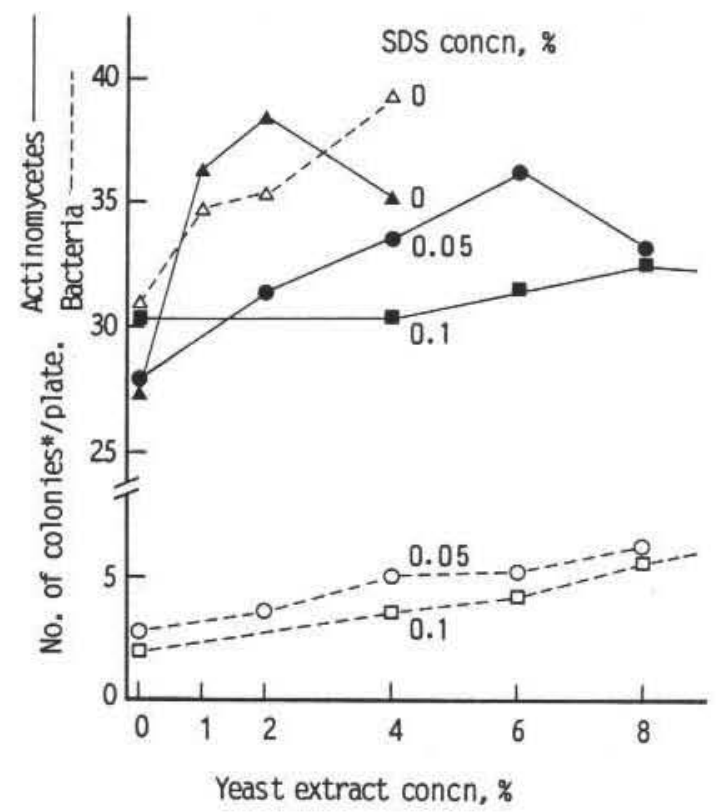

Fig. 2. Optimal concentrations of yeast extract and SDS in combined use, in the pretreatment $\left(40^{\circ} \mathrm{C}, 20 \mathrm{~min}\right.$.) of soil in P-buffer (5 mM, pH 7.0) for selective isolation of actinomycetes. (Soil No. 405. HV agar).

* After 3 weeks at $30^{\circ} \mathrm{C}$.
Table 4. Effects of the combined use of SDS with the other spore-activating agents on isolation of actinomycetes from a soil sample (No. 405).

\begin{tabular}{|c|c|c|}
\hline \multirow{3}{*}{$\begin{array}{l}\text { Treatment* } \\
40^{\circ} \mathrm{C} \text {, } \\
20 \mathrm{~min} .\end{array}$} & \multicolumn{2}{|c|}{$\begin{array}{l}\text { No. of colonies } \\
(\mathrm{cfu} / \mathrm{g} \text { of soil**) }\end{array}$} \\
\hline & $\begin{array}{l}\text { Actino- } \\
\text { mycetes }\end{array}$ & Bacteria \\
\hline & $x 10^{5} \quad$ (\%) & $\mathrm{x} 10^{5}(\%)$ \\
\hline None (Control) & $117(100)$ & $160(100)$ \\
\hline $\mathrm{SDS}+\mathrm{YE} 6 \%$ & $183(157)$ & $22(14)$ \\
\hline$"$ + HA $1 \%$ & $173(148)$ & $9(5)$ \\
\hline$"+\mathrm{CA} 1.5 \%$ & $153(131)$ & $15(9)$ \\
\hline$"+V a 0.6 \%$ & $147(126)$ & $19(12)$ \\
\hline$"+\mathrm{ME} 0.1 \%$ & $158(135)$ & $14(8)$ \\
\hline
\end{tabular}

* $0.05 \%$ SDS was dissolved in $5 \mathrm{mM}$-phosphate buffer ( $\mathrm{pH} 7.0$ ). For abbreviations see Table 3 . HV agar was used for isolation.

** After 3 weeks at $30^{\circ} \mathrm{C}$.
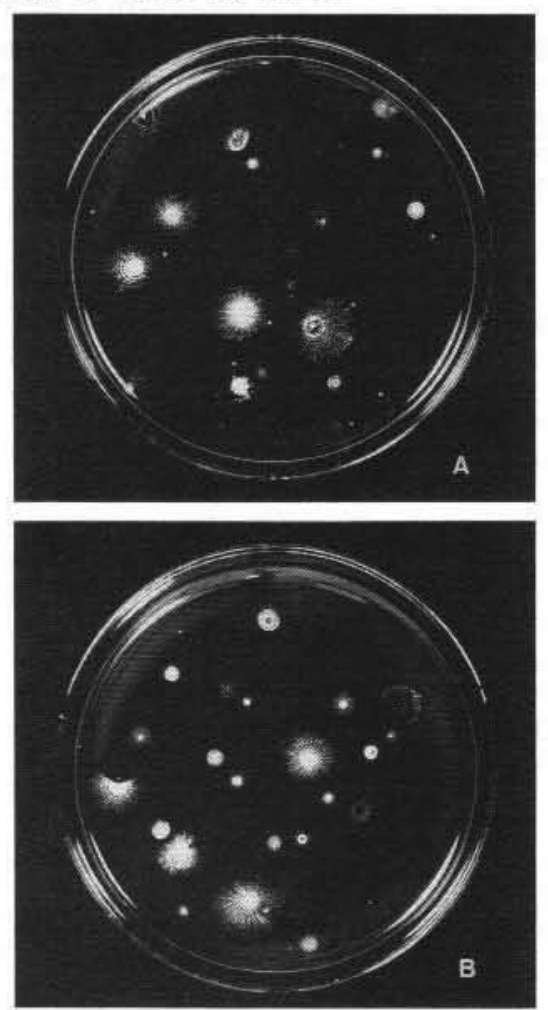

Fig. 3. Selective isolation of general actinomycetes from the soil No. 405. HV agar. 3 weeks at $30^{\circ} \mathrm{C}$. Dilution $2 \times 10^{-6}$ ). A: Control, B: Pre-treatment at $40^{\circ} \mathrm{C}$ for $20 \mathrm{~min}$. with $6 \% \mathrm{YE}$ and $0.05 \%$ SDS in $5 \mathrm{mM}$ P-buffer ( $\mathrm{pH} 7.0)$. 


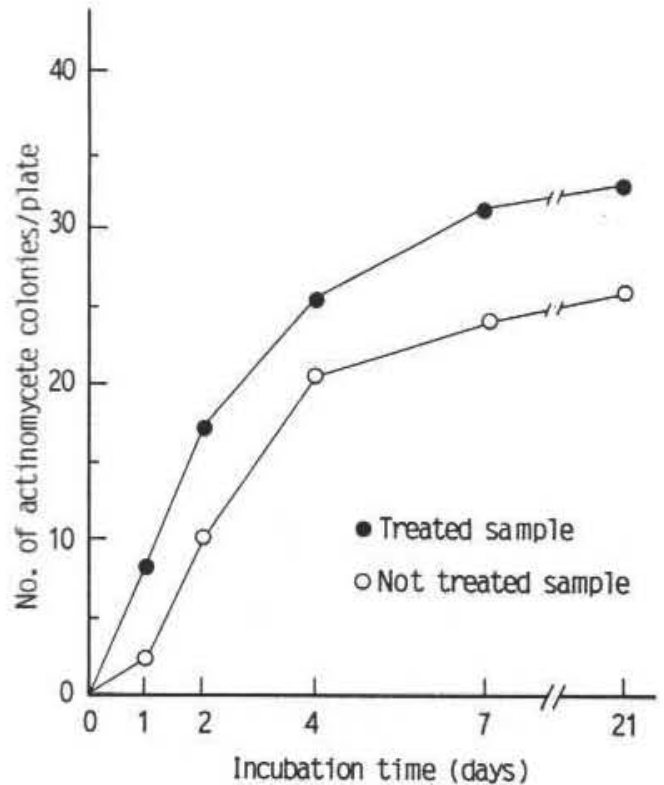

Fig. 4. Increase in actinomycetes number and colony formation rate by the pretreatment of soil (No.323) suspension. (see Fig. 3).
Application of the new method to various soil samples. The efficiency of the soil pretreatment with $6 \% \mathrm{YE}$ and $0.05 \% \mathrm{SDS}$ at $40^{\circ} \mathrm{C}$ for $20 \mathrm{~min}$. was confirmed using 10 soil samples collected from cultivated fields, paddy rice fields, forests and pasture (Table 5). The treatment increased actinomycete cfu by about $40 \%$, and decreased bacterial count to about $20 \%$, on the averages. In 5 soil samples (No. $346,381,384,389$ and 403), the numbers of actinomycete cfu brought by the treatment were significantly larger $(P<0.01)$ than the numbers on control plates. In all of the samples, bacterial counts were decreased significantly $(\mathrm{P}<0.001)$ by the treatment. Addition of nalidixic acid (20 $\mathrm{mg} / \mathrm{L}$ ) into the isolation medium, HV agar, further decreased the bacterial count to less than $10 \%$ on an average, while no decrease in the number of actinomycete cfu was observed in this case.

Procedure of the new method. From the results obtained above, the following

Table 5. Isolation of actinomycetes from various soils by the new method*.

\begin{tabular}{|c|c|c|c|c|c|c|}
\hline \multirow{2}{*}{$\begin{array}{l}\text { Soil } \\
\text { sample } \\
\text { (type) }\end{array}$} & \multicolumn{3}{|c|}{$\begin{array}{l}\text { Untreated control } \\
\text { on HV agar }\end{array}$} & \multicolumn{2}{|c|}{$\begin{array}{l}\text { Treated with YE } \\
\text { on HV agar }\end{array}$} & \multirow{2}{*}{$\begin{array}{l}\text { and SDS* } \\
\text { on HV+n.a.** } \\
\underset{\%}{\text { Bacteria }}\end{array}$} \\
\hline & $\begin{array}{l}\text { Actino. } \\
\times 10^{5} / \mathrm{g}\end{array}$ & $\begin{array}{l}\text { Actino. } \\
\text { (control) }\end{array}$ & $\begin{array}{c}\text { Bacteria } \\
\%\end{array}$ & $\underset{\%}{\operatorname{Actino}}$ & $\begin{array}{c}\text { Bacteria } \\
\%\end{array}$ & \\
\hline \multicolumn{7}{|l|}{ (Field) } \\
\hline No. 375 & 90 & 100 & 477 & 117 & 68 & 24 \\
\hline No. 377 & 149 & 100 & 320 & 114 & 36 & 17 \\
\hline No. 384 & 127 & 100 & 260 & 143 & 24 & 9 \\
\hline No. 389 & 134 & 100 & 921 & 146 & 271 & 128 \\
\hline No. 403 & 104 & 100 & 320 & 163 & 77 & 33 \\
\hline \multicolumn{7}{|c|}{ (Paddy field) } \\
\hline No. 381 & 7 & 100 & 1905 & 168 & 397 & 170 \\
\hline $\begin{array}{l}\text { No. } 401 \\
\text { (Forest) }\end{array}$ & 25 & 100 & 1180 & 104 & 204 & 90 \\
\hline No. 346 & 11 & 100 & 137 & 157 & 79 & 25 \\
\hline No. 378 & 24 & 100 & 226 & 134 & 60 & 30 \\
\hline \multicolumn{7}{|l|}{ (Pasture) } \\
\hline No. 388 & 91 & 100 & 1426 & 140 & 122 & 63 \\
\hline Average & & 100 & 717 & 139 & 134 & 59 \\
\hline
\end{tabular}

*Pretreatment of soil suspension with yeast extract(YE) and sodium dodecyl sulfate(SDS), dilution, inoculation on HV agar plates containing nalidixic acid(n.a.) and a few week's incubation at $30^{\circ} \mathrm{C}$. Increase of actinomycetes and decrease of bacteria). $6 \%$ YE and $0.05 \%$ SDS, in 5 $\mathrm{mM}$ P-buffer $(\mathrm{pH} 7.0)$ at $40^{\circ} \mathrm{C}$ for $20 \mathrm{~min}$.

**No decrease in number of actinomycetes was observed by addition of nalidixic acid $20 \mathrm{mg} / \mathrm{L}$. 


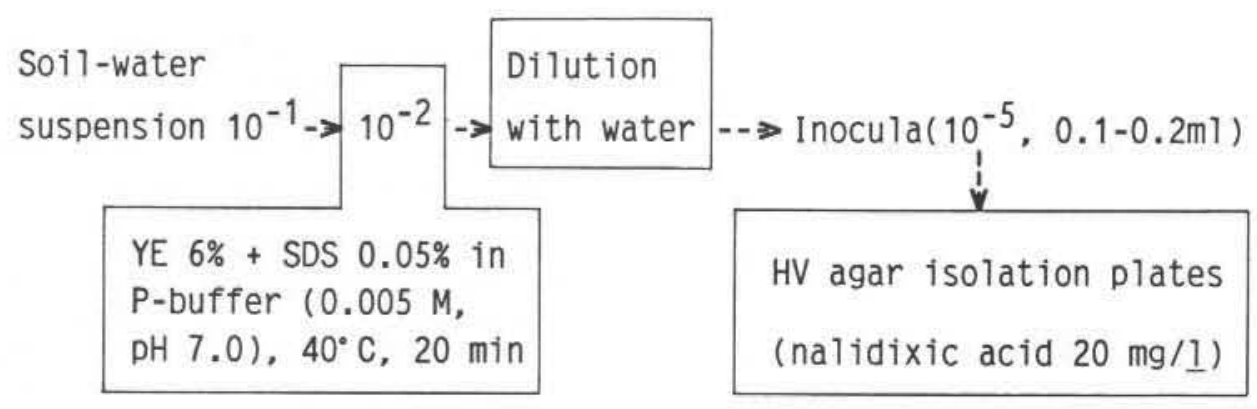

Fig. 5. Scheme for isolation of actinomycetes from soil.

procedure (Fig. 5) was set up as a new, useful method for the selective isolation of actinomycetes from soil. Sieved and air dried soil is used as the samples. The dilution after the pretreatment of soil suspension is necessary to remove the action of $\mathrm{YE}$ and $S D S$ in isolation plates, because YE promotes bacterial growth, and SDS injures germinating spores of actinomycetes. To obtain a clear result, 2-3 weeks incubation and development of 20-40 colonies of actinomycetes per plate are desirable.

\section{DISCUSSION}

Several agents including $\mathrm{YE}^{34}$ ), $\operatorname{SDS}^{36}$ ) and heat $\operatorname{shock}^{35}$ ) have been reported to stimulate the germination of actinomycete spores. However, none of these spore-activating agents have been applied to the isolation of actinomycetes. We found that the pretreatment of soil suspension with YE, SDS and heat shock $\left(40^{\circ} \mathrm{C}, 20 \mathrm{~min}.\right)$ resulted in increase of both actinomycete recovery (Tables 4 and 5 ) and the rate of colony formation on isolation plates (Fig. 4). These effects are considered to be due to the form of actinomycetes in soil. Direct observation using scanning electron microscope ${ }^{37)}$, homogenization technique ${ }^{37}$ ), the study of actinostasis by soil ${ }^{38,39)}$ and other experiments 40,41 ) have indicated that the actinomycetes in soil exist largely in the form of dormant spores in their life cycle.

Elimination of bacteria from actinomycete isolation plates is an important problem. We found that a detergent, SDS, acted not only as a spore activator of actinomycetes but also as a selective germicide to soil bacteria. The pre- treatment of soil suspension with SDS killed most of bacteria, while increasing actinomycete recovery (Tables 3,4 and 5). This is an advantage when compared with the phenol treatment11) which has been reported to, as a result of restudying ${ }^{2}$ ), cause reduction in the number of actinomycetes as well as bacteria. The germicidal action of SDS was removed easily by dilution with water. This is more advantageous than benzalkonium chloride treatment12) which needs an inactivator. Bacterial spores were resistant to SDS (Table 2). However, HV agar limited bacterial growth and the addition of nalidixic acid $(20 \mathrm{mg} / \mathrm{L})$ into HV agar inhibited bacterial growth without affecting the actinomycete growth (Table 5). Barton and Hughes ${ }^{42}$ ) used a selective medium containing nalidixic acid and other antibiotics for the isolation of Rhodococcus strains. Wakisaka ${ }^{43}$ showed that the Streptomyces and Micromonospora strains tested were resistant to nalidixic acid. However, this antibiotic has not been used for the isolation of actinomycetes in general.

The pretreatment of soil suspension with spore activating agent and germicide at $40^{\circ} \mathrm{C}$ for $20 \mathrm{~min}$. greatly increased the recovery of actinomycetes from various soil samples (Table 5). This pretreatment has been proved effective even when combined with agars other than the HV agar, such as starch-casein-nitrate agar's), glycerolarginine agar ${ }^{2}$ and AV agar ${ }^{13)}$, supplemented with nalidixic acid $10-20 \mathrm{mg} / \mathrm{L}$ (data not shown). Thus, this pretreatment will be applicable to the study of the ecology of a variety of actinomycetes as well as to the search for useful strains of these organisms. 


\section{ACKNOWLEDGEMENT}

The authors are grateful to Mr. Kenji Tanno for helpful suggestions and Mr. Hiromitsu Iino for technical assistance.

\section{REFERENCES}

1) Goodfellow, M.: Ecology of actinomycetes. Ann. Rev. Microbiol. 37: 189216, 1983.

2)El-Nakeeb, M. A. \& H. A. Lechevalier: Selective isolation of aerobic actinomycetes. Appl. Microbiol. 11: 75$77,1963$.

3) Kuster, E. \& S. T. Williams: Selection of media for isolation of streptomycetes. Nature 202: 928-929, 1964.

4)Williams, S. T. \& F. L. Davies: Use of antibiotics for selective isolation and enumeration of actinomycetes in soil. J. Gen. Microbiol. 38: 251$261,1965$.

5) Lingappa, Y. \& J. L. Lockwood: A chitin medium for isolation, growth and maintenance of actinomycetes. Nature 189: 158-159, 1961.

6)Hsu, S. C. \& J. L. Lockwood: Powdered chitin agar as a selective medium for enumeration of actinomycetes in water and soil. Appl. Microbiol. 29: 422$426,1975$.

7)Tsao, P. H.; C. Leben \& G. W. Keitt: An enrichment method for isolating actinomycetes that produce diffusible antifungal antibiotics. Phytopathology 50: 88-89, 1960.

8)Williams, S. T.; M. Shameemullah, E. T. Watson \& C. I. Mayfield: Studies on the ecology of actinomycetes in soil. VI. The influence of moisture tension on growth and survival. Soil Biol. Biochem. 4: 215-225, 1972.

9)Rowbotham, T. J. \& T. Cross: Ecology of Rhodococcus coprophilus and associated actinomycetes in fresh water and agricultural habitats. J. Gen. Microbiol. 100: 231-240, 1977.

10) Hirsch, C. F. \& D. L. Christensen: Novel method for selective isolation of actinomycetes. Appl. Environ. Microbiol. 46: 925-929, 1983.

11)Lawrence, C. H.: A method of isolating actinomycetes from scabby potato tissue and soil with minimum contamination. Can. J. Bot. 34: 44-47, 1956.

12)Cross, T.: Actinomycetes: a continuing source of new metabolites. Develop. Indust. Microbiol. 23: 1-8, 1982.

13) Nonomura, H. \& Y. Ohara: Distribution of actinomycetes in soil. VI. A culture method effective for both preferential isolation and enumeration of Microbispora and Streptosporangium strains in soil (Part I). J. Ferment. Technol. 47: 463-469, 1969.

14)Nonomura, H. \& Y. Ohara: Distribution of actinomycetes in soil. VIII. Green spore group of Microtetraspora, its preferential isolation and taxonomic characteristics. J. Ferment. Technol. 49: 1-7, 1971.

15)Nonomura, H. \& Y. Ohara: Distribution of actinomycetes in soil. IX. New species of the genera Microbispora and Microtetraspora, and their isolation method. J. Ferment. Technol. 49: 887-894, 1971.

16)Nonomura, H. \& Y. Ohara: Distribution of actinomycetes in soil. $X$. New genus and species of monosporic actinomycetes. J. Ferment. Technol. 49: 895-903, 1971.

17)Nonomura, H. \& Y. Ohara: Distribution of actinomycetes in soil. XI. Some new species of the genus Actinomadura Lechevalier et al. J. Ferment. Technol. 49: 904-912, 1971.

18) Nonomura, H. \& Y. Ohara: A new species of actinomycetes, Thermomonospora mesouvi'ormis sp. nov. J. Ferment. Technol. 52: 10-13, 1974.

19) Palleroni, N. J.: A chemotactic method for the isolation of Actinoplanaceae. Arch. Microbiol. 128: 53$55,1980$.

20)Athalye, M.; J. Lacey \& M. Goodfellow: Selective isolation and enumeration of actinomycetes using rifampicin. J. Appl. Bacteriol. 51: 289-297, 1981.

21)Cross, T. \& R. W. Attwell: Recovery of viable thermoactinomycete endospores from deep mud cores. In "Spore research 1973", ed. A. N. Barker, G. W. Gould \& J. Wolf, pp.11-20, Academic Press, London, 1974.

22)Orchard, V. A. \& M. Goodfellow: The selective isolation of Nocardia from soil using antibiotics. J. Gen. Microbiol. 85: 160-162, 1974.

23)Wakisaka, Y.; Y. Kawamura, Y. Yasuda, K. Koizumi \& Y. Nishimoto: A selective isolation procedure for Micromonospora. J. Antibiotics 35: 822-836, 1982.

24)Hanka, L. J. \& R. D. Schaadt: Methods for isolation of stretptoverticillia from soils. J. Antibiotics 41: 576$578,1988$. 
25)Williams, S. T. \& E. M. H. Wellington: Principles and problems of selective isolation of microbes. In "Bioactive microbial products: search and discovery" ed. J. D. Bu'lock, L. $J$. Nisbet and D. J. Winstanley, pp.9-26, Academic Press, New York London, 1982.

26) Davies, F. L. \& S. T. Williams: Studies on the ecology of actinomycetes in soil. I. The occurrence and distribution of actinomycetes in a pine forest soil. Soil Biol. Biochem. 2: 227-238, 1970.

27) Hayakawa, M. \& H. Nonomura: Humic acid-vitamin agar, a new medium for the selective isolation of soil actinomycetes. J. Ferment. Technol. 65: 501-509, 1987.

28) Nonomura, H. \& Y. Ohara: Distribution of actinomycetes in soil. IV. The isolation and classification of the genus Microbispora. J. Ferment. Technol. 38: 401-405, 1960.

29)Nonomura, H. \& Y. Ohara: Distribution of actinomycetes in soil. V. The isolation and classification of the genus Streptosporangium. J. Ferment. Technol. 38: 405-409, 1960.

30)Hayakawa, M. \& H. Nonomura: Distribution of rare actinomycetes in Japanese soils. J. Ferment. Technol. 66: 367-373, 1988.

31)Nonomura, H. \& Y. Ohara: Distribution of actinomycetes in soil. VII. A culture method effective for both of preferential isolation and enumeration of Microbispora and Streptosporangium strains in soil (Part II.). J. Ferment. Technol. 47: 701-709, 1969.

32)Dept. Agr. Chem., Tokyo Univ.: Experiments in agricultural chemistry, Vol. II, p.180, Asakura-Shoten, Tokyo, 1978.

33) Quesnel, L. B.; B. L. Scott \& J. L. Taylor: The effect of dimethylsulphoxide on the survival and germination of Bacillus subtilis spores. In "Spore research 1971", ed. A. N. Barker, G. W. Gould \& J. Wolf, pp.303-314, Academic Press, London, 1971.

34)Hirsch, C. F. \& J. C. Ensign: Nutritionally defined conditions for germination of Streptomyces viridochromogenes spores. J. Bacteriol. 126: $13-23,1976$.

35) Hirsch, C. F. \& J. C. Ensign: Heat activation of Streptomyces virido- chromogenes spores. J. Bacteriol. 126: $24-30,1976$.

36)Grund, A. D. \& J. C. Ensign: Activation of Streptomyces viridochromogenes spores by detergents. Current Microbiol. 7: 223-228, 1982.

37) Mayfield, C. I.; S. T. Williams, S. M. Ruddick \& H. L. Hatfield: Studies on the ecology of actinomycetes in soil. IV. Observations on the form and growth of streptomycetes in soil. Soil. Biol. Biochem. 4: 79-91, 1972.

38)Kamata, S. \& H. Nonomura: Inhibitory effect of raw soil on the growth of actinomycetes. Abstract of papers, the anual meeting of the Agricultural Chemical Society of Japan, Tokyo, P.264, 1975.

39)Ho, W. C. \& W. H. Ko: Microbiostasis by nutrient deficiency shown in natural and synthetic soils. J. Gen. Microbiol. 132: 2807-2815, 1986.

40)Lloyd, A. B.: Behaviour of streptomycetes in soil. J. Gen. Microbiol. 56: 165-170, 1969.

41)Williams, S. T.: Streptomycetes in soil ecosystem. In "Nocardia and Streptpmyces" ed. M. Mordarski, W. Kurylowicz \& J. Jeljaszewicz, pp.137-144, Gustab Fischer Verlag, Stuttgart, New York, 1978.

42)Barton, M. D. \& K. L. Hughes: Comparison of three techniques for isolation of Rhodococcus (Corynebacterium) equi from contaminated sources. J. Clin. Microbiol. 13: 219-221, 1981.

43)Wakisaka, Y. \& K. Koizumi: A selective isolation procedure for Pseudomonas bacteria. J. Antibiotics 35 : 622-628, 1982.

44)Hayakawa, M. \& H. Nonomura: Heavy metal resistance and melanoid pigment production in the streptomycete flora of copper-polluted vineyard soils. Hakkokogaku 60: 1-9, 1982.

45)Hesseltine, C. W.; R. G. Benedict \& T. G. Pridham: Useful criteria for species differentiation in the genus Streptomyces. Ann. N.Y. Acad. Sci. 60: 136-151, 1954. 